\title{
Factors that Influence the Teaching of the English Language during the Transition from Primary to Secondary School in Eighth-Grade Students from Guayaquil
}

\author{
Israel Guillermo Bravo Bravo', Maria Palmira Alves² \\ ${ }^{1}$ University of Guayaquil, Guayaquil, Ecuador \\ ${ }^{2}$ University of Minho, CIEC, Braga, Portugal \\ Email: israel.bravob@ug.edu.ec,palves@ie.uminho.pt
}

How to cite this paper: Bravo, I. G. B., \& Alves, M. P. (2021). Factors that Influence the Teaching of the English Language during the Transition from Primary to Secondary School in Eighth-Grade Students from Guayaquil. Open Journal of Social Sciences, 9, 106-126.

https://doi.org/10.4236/jss.2021.94010

Received: February 20, 2021

Accepted: April 16, 2021

Published: April 19, 2021

Copyright $\odot 2021$ by author(s) and Scientific Research Publishing Inc. This work is licensed under the Creative Commons Attribution International License (CC BY 4.0).

http://creativecommons.org/licenses/by/4.0/

\begin{abstract}
This study's general objective was to determine the influence of the factors that impact the English language teaching during the transition from primary to secondary school in eighth-grade students in public education in Guayaquil city. The current research was developed under the positivist approach, with a non-experimental, cross-sectional, descriptive, and correlational type. A 24 response items questionnaire gathered quantitative data through a survey technique with a sample of 469 English teachers. The results obtained indicate the relationship between English language learning acquired by the students and the required preparation to face academic content in greater quantity and complexity. It also shows the teacher-student relationship, considering the need for the teacher to apply higher and progressive content adapted to the results of the diagnosis of previous knowledge in students and the implementation of activities that promote the establishment of close relationships with the student.
\end{abstract}

\section{Keywords}

English, Transition, Teaching-Learning Process, Public Education, Academic Development

\section{Introduction}

This research focuses on binding and wide-ranging situation implications for high school students' educational performance, such as the transition between primary and secondary education and the English language learning. In Ecua- 
dor, this educational transition is observed when students move to the eight grade of Basic General Education (BGE). This process appears to be academically intensified due to the fact that until 2016 there had not been an English language curriculum for the first seven years of BGE. Similarly, research has also evidenced social and environmental factors that affect this transitional process in schools. In essence, this study seeks to determine, analyze, and interpret how some of these factors that operate during this transition influence the level of learning acquired by the student, especially the way eighth-grade teachers of public education in Guayaquil city address such factors in their curricular planning.

It is a transition that occurs when the student leaves an educational context of having a single teacher for all school subjects to enter a multiple teacher environment. However, beyond this fundamental difference, there are vast differences in organizational cultures. In this context, it is a study where the main pedagogical and psychosocial problems students face during this stage break in their school life, and that serves as a prelude to other transits in their academic development.

Castro, Ezquerra and Argos (2012) understand this process as a "reference to the change that children make from one educational phase to another" (p. 219), arguing that such changes may affect the student providing benefits or, on the contrary, they pose obstacles or difficulties during the educational journey. For his part, Gairín (2004) states that transition processes are always problematic, since in the extent to which they involve a transformation of the normative and orientation context of training, to the same extent will affect the emotional and social processes of the student. However, the author warns they should be understood as an opportunity for students to adapt to diversity in any case.

Hence, this investigative approach is to deepen the study of the causes from the perspective described that could influence learning English at this educational level. On the one hand, this means finding answers to many questions about how students respond to certain educational initiatives or strategies. On the other hand, make recommendations to raise awareness about the importance of this educational transition and teaching support that you must have to avoid negative experiences in your English learning.

\subsection{Topic Formulation}

The transition from primary to secondary school is a classic theme in educational life and somewhat ambivalent. Because, while some children (and their parents) make the transition smoothly, others will find the transformation stressful and challenging, showing their responses in many ways (Griebel \& Niesel, 2004).

There are both positive and negative factors associated with the transition to school secondary to awareness of individuality, own ability, and student mental health (Griebel \& Niesel, 2004). Some of these factors are associated with family or social environments, such as parents and the child's emotional relationship. In contrast, others are more linked to the institutional part, such as curricular 
teaching planning. However, in any case, the effects are those that determine how easy or difficult the transition will be achieved.

According to literature, the transition from primary to secondary has been addressed in certain subjects, such as the arithmetic transition to algebra that operates in prolonging mathematical studies. However, in subjects like English, research production is less abundant even when there is a consensus that learning a second language could be stressful initially. It determines students' progress in higher educational cycles if the requirements are not taken to motivate them.

Authors such as Fabuel (2015) argue that this initial meeting of the student with English as part of the new experience raises the transition from primary to secondary. It largely depends on their disposition for learning this language and others in the future. In other words, the success or failure of certain factors during the transition influence, the teaching approach of these factors, and how English learning is characterized in this new educational cycle with the influence of these factors will depend on the performance of the student and their learning in the upcoming educational levels.

Hence, considering these important implications in the student's academic future, the development of a descriptive level field investigation is proposed seeking to identify the factors involved in the transition from primary to secondary school, which influences the English learning process. And assesses how the teachers of public education in Guayaquil city perform towards such factors.

\subsection{General Objective}

To determine the influence of the factors that affect the teaching of the English language during the transition from primary to secondary school in eighth graders of public education in Guayaquil city.

\subsection{Specific Objectives}

- To describe the transition model from the English language teaching and learning process perspective in students moving from primary to secondary school.

- To identify the factors involved in the transition that influence the learning of English of eighth-grade students.

- To analyze the teaching role assumed with the transition factors that influence English learning in eighth grade of public education in Guayaquil city.

\subsection{Hypothesis}

The eighth-grade teachers of public education in Guayaquil city do not consider in their educational planning the factors of the transition from primary to secondary incidents in the teaching of the English language. In many cases, this produces a lack of motivation in the student, affecting their learning and future academic performance. 


\section{Development}

\subsection{The Transition from Primary to Secondary School}

According to the RAE (2019), the word transition is equivalent to change, move, the action of changing or passing from one state to another. The alteration in the way of being or being, or in the way of doing things. Change, transition, and adaptation are constant processes in the life of all human beings.

The man from birth is marked by the processes of change accompanied by different assimilation and adaptation moments. These changes can generate unease feelings, such as anxiety, anguish, insecurity, and frustration. All of them are added as a natural part of the learning process, but to control and overcome them influences the individual's ability to adapt. But it is not only a question of motivation and willingness on the part of the subject to fit in with the environment and given circumstances. It will also largely depend on the conditions and factors provided by the means in favor of this adaptive process (Gaviria, 2016).

According to Gaviria (2016), two types of transitions can be distinguished: horizontal and vertical. The first occurs throughout the entire existence daily life of the individual. It is related to the movements that any person does routinely between different fields or aspects in life. And the vertical transitions are those made within the context of regular education and represent the passage from one educational level to another. These types of transitions are what is analyzed in the present study. The transition in educational levels, described by Fabian and Dunlop (2007), explains this vertical transition due to the completion and achievement of a curricular program to which the student is attached and as a model conceived in society. It has social and cultural implications, defining them as an inherent part of the school system, where advancement or promotion in such assumes "a set of steps or levels that respond to the educational system's organization, which structures divisions or parcels, more or less arbitrary, in the knowledge, in the schedules, in the students and the teachers." (p. 51). In this sense, the educational process includes stages and cycles that must go through and overcome the child, youth, adolescent or adult who is immersed in this system, and it is engaged in a teaching and learning process. The three types of transitions most characterized related to the educational system are: 1) those that occur with the entrance to an educational center from the family environment, 2) those which happen within the school system, and 3) those that are established from the last stage to adult life, the work and professional environment. Move from one stage to another within this trajectory, it supposes for the individual changes that are manifested not only in the immediate educational environment of those who live it, but in the different scenarios and aspects of his life. Regarding those that occur within the educational system, the transition between educational stages is a process that can be complex for students, since for each one there is a learning modality, and the student at the end of a stage, for example, primary school leaves this model behind to plunge into another, that of the secondary, which demands greater responsibility while granting him 
some freedom, to organize their study routines according to the new subjects that are presented to them. Thus, there is a kind of collision between both learning modalities, and for the adaptation of the student to their new circumstances, educational system support is key, but also of the entire environment that surrounds it (Hiraldo, 2018). The transition between educational stages is therefore a process that not only involves students who experience it in the first person, but also concerns parents, teachers and active members of the education system, that is, the entire environment that surrounds the student, given the implications it generates at an academic, social and emotional level for them. Lack of collaboration and coordination between educational institutions primary and secondary school involved in this process, is a major difficulty between which, according to Antunez (2005), it is necessary to face and adjust such communication for the student. According to Wilcock (2014), the transition from primary school to secondary school is also an extremely important event that parents experience accompanying this process that the children go through. This author argues that this process goes far beyond a change of institution and facilities to the student and their environment. It also involves a change in teachers, subjects, assessment modes, and teaching methods. It generates great changes not only on an academic level but also on a physical, emotional, social, and cognitive level. All this translates into a complex moment that the student lives, which adds to his adolescent process, which in many cases represents a true challenge for that environment that surrounds them and dwells day to day with them. Because, although it does not seems to be, it is a real change. Vogler et al. (2008) on transitions maintains that apart from the transformations related to infrastructure and the social circle. Also, "there are modifications in contact with convictions, speeches, and practices conditioned by culture, especially when such modifications have to see changes in the environment and, sometimes, in the predominant language" (p. 37). In addition to the external changes that student experiences when entering secondary school, the contact with a new language, English, at a higher level, is added as another factor that must work in the transition and adaptation in this new stage of their educational instruction. In the case of Ecuador, specifically in Guayaquil, with a quarter of the students in the entire coastal area, the schoolchildren spend seven years in primary education before advancing to secondary education. Parents take on that moment, based on advice from the teaching staff and many times, depending on their financial situation, the decision whether the child should continue their school career in a public or private institution. For the families who choose an institution that offers both stages together, this transition for the student becomes more bearable. Instead, for those students who must change institutions, anxiety may be generated towards the new, which transcends to some area of knowledge that they face for the first time, as is the case of learning the English language.

\subsection{Transition Models}

Transitions are complex processes of change within the individual, embedded in 
communication with their social environment. They are phases of life associated with high demands, and changing environments mean the accumulation of stress factors (Welzer, 1993). Bronfenbrenner (1979) defined an individual's transition from the family to an educational institution as an ecological transition. The displacement between familiar settings such as the primary developmental context and the school setting as a secondary development context requires adjustment and causes changes in identity, relationships, and roles. Adaptation to new demands has been studied within the stress paradigm. Theories about stress (Lazarus \& Folkman, 1987) as well as critical life events (Filipp, 1981) consider an evaluation of the critical event (challenge, threat, or failure) as important. It is not the event alone, but the coping process that turns into a transition. Development throughout life takes into consideration not only the development of the child but also the transition in parents. Starting from the background of the theory of family development, Cowan's (1991) concept of family transition is adaptable to the multiple demands regarding the transitions between the family and the educational system. From a social-constructivist perspective, the transition is a coconstruction process through communication and participation between institutions and families (Griebel \& Niesel, 2004). Parents support their child's transition and transition themselves to be the parents of a school-age child. Early childhood and school institutions' staff members co-construct the transition but are not directly affected by the development tasks themselves (Griebel \& Niesel, 2004). While this approach is common in the transition from home to school primary school, it can also be applied to the transition from primary school to secondary school. The success of any transition is understood as a coping process. It is achieved when all parts involved in the transition understand and accept it. Students' well-being (and their parents) within the new institution is then essential for successful interaction and learning (Griebel \& Niesel, 2004; Lazarus \& Folkman, 1987). Table 1 shows the challenges to be addressed within the transition process in the educational system:

To face the challenges described, parents have a dual role during the transition period, managing to cope with the process by themselves and to support the child during the process. For children and parents who are experiencing the transition to secondary school, an overview of challenges and strategies to apply at different levels revolves around discipline topics. Discipline is one of the fundamental elements of success or failure in the educational system by students.

Table 1. Levels of challenges in the transition process according to Griebel and Niesel (2004).

\begin{tabular}{cc}
\hline Challenge level & Implications \\
\hline Individual & Identity, emotions, and capacity \\
Interactional & Loss and construction of new relationships, social roles \\
Environmental & New environments, curricula and learning experiences \\
\hline
\end{tabular}

Source: Griebel \& Niesel (2004). 
Concerning the above, the literature indicates that if a student can invest the time necessary to fulfill the subjects' tasks, possibly, be able to conclude each level successfully. On the other hand, the results of studies such as those of Wilcock (2014) they evidence that the learning environment influences the motivation of students. The interpersonal relationships skills that the teacher establishes with his students could be decisive for them and one of the fundamental personal qualities in a communicative teacher. On the other hand, in addition to the interpersonal relationships that establish students and teachers, there are also academic resources and capacity that the latter must overcome the challenges posed by the transition from primary to secondary.

\subsection{Theories of Teaching English}

According to Arechúa (2012), it is known as the acquisition of a second language to how the person learns and internalizes a language other than their predominant mother tongue or native language. Second language acquisition is a natural process in bilingual infants whose parents or relatives communicate through two or more languages. On the other hand, if this process is carried out in older ages, already by an adult, it is proven by applied linguistics that this learning process contrasts its phases of acquiring the first. It is because other types of cognitive skills are needed. Therefore, learning a second language is a more rigorous process where more time would be required. Especially when structurally the first language and the second one is very different.

Barrezueta and Merlo (2010) point out that the acquisition of a second language is a more advantageous, meaningful, and accurate process when used in a real communication situation, which is why it is the responsibility of the teachers to explain the fundamentals that the language requires from the first years of the school stage. The regularity of learning for social language is different from that of academic language learning. Within appropriate contexts, the average of a second language takes about two years to gain elementary interpersonal communication skills. These skills go into language daily due to the demands of the integrated context that contains the interlocutor. However, it takes between five and seven years, under suitable circumstances, to develop the Cognitive academic language proficiency or the academic language of little context, to a degree like that of those who study in their native language. Barrezueta and Merlo (2010) conclude that most English learners who learn English as a second language have problems in certain aspects. Although they dominate seemingly ideally traditional basic English for communication daily, they have problems with cognitive academic linguistic skills.

There are various explanatory theoretical positions of how the acquisition of a second language occurs, being one of the most used theoretical approaches that of Krashen and Terrel, a model that, according to Cerdas and Ramírez (2015), is divided into five hypotheses: 1) acquisition-learning, 2) natural order, 3) selfmonitoring, 4) the "Input" and 5) the affective filter. According to the learn- 
ing-acquisition hypothesis, people have two ways to develop a foreign language's linguistic competence, either through learning or acquisition. According to this theoretical perspective, language acquisition is a process like how the language is learned; that is, without formal training, without handling the rules of grammar or pronunciation patterns of how to speak Spanish. Krashen and Terrel (1983) describe this process as a "natural way to develop capacity linguistics, and it is a subconscious process" (p. 2). Therefore, the language acquisition process would be related to unconscious learning, in which language is acquired naturally in communicative contexts, and there is no formal teaching. On the other hand, within the natural order hypothesis, learning a foreign language occurs as part of a conscious process where there is formal instruction. There is also formal knowledge of the language, noting Krashen and Terrel (1983) that in this case, learning a certain language starts from the "explicit knowledge of the rules, being aware of it and having the capacity to talk about it" (p. 2). According to the monitor hypothesis, when the language acquisition system processes a statement, the knowledge obtained from learning the language (conscious learning) will oversee correcting expressions. It means that what Krashen calls the "sense of correction" is sometimes used to edit sentences produced in the mother tongue and the target language. The learning conscious has only the function of correcting the statements and not starting production in a second language. It is the knowledge of the language that enters in play when correcting one's expressions, either before, now, or immediately after they have been spoken. According to Hockett (1967), two processes are used to correct expressions: external correction and internal correction. External correction is the process that takes place when the expression is repaired or edited after it has occurred. On the contrary, the edition is a process by which what is intended to be said has been corrected and edited before it is said. This process is somehow less obvious because what is usually heard is the correct expression.

The input hypothesis states that people can acquire language when they understand and are exposed to a constant linguistic stimulus that is a little above the current level of competition. According to Krashen and Terrel $(i+1)$, " $i$ " is the linguistic stimulus level, and " 1 " has to do with a linguistic stimulus that is part of the next stage of learning the individual. The linguistic stimulus given to the student must have structures known by it and must also include some structures or vocabulary that form part of the next stage of learning, and he must be clear about this process. It means for students to improve their proficiency, students, teachers, and the educational system that contains them must provide them with linguistic material beyond their proficiency level.

Finally, the affective filter hypothesis, perhaps one of the most important in teaching foreign languages, refers to the part affective and dispositional on the part of the student. It states that when a student has a positive outlook towards the learning process, you will be more successful in acquiring the foreign language that students who are not motivated to respect. Therefore, it is important 
to promote a welcoming classroom environment and in them as much as possible free of stress and feelings of anguish, which "will allow students to increase their receptive and productive capacity" (Krashen \& Terrel, 1983: p. 1).

\subsection{Teaching Role in the Transition from Primary to Secondary School}

Considering the transition process is important to highlight the teacher's relationship with their students as a crucial classroom education factor. Because his daily and constant pedagogical practice can generate an atmosphere promoting trust, security, and order, which is oriented to the teaching and learning process and contributes to the adaptation of students that receives from primary education levels. Regarding this relationship Voli (2005) refers that in pursuit of teaching effectiveness, "The teacher can and should realize what he is doing and what he can do in his classroom to create an environment favorable to good self-esteem of their students and coexistence that facilitates this work" (p. 37). Thus, the entrance teacher's performance must be oriented towards fostering in the student the confidence that quickly adapts to the new educational environment. In this sense, one of the main teaching tasks to achieve this trust and rapid adaptation of the student is to diagnose their previous knowledge. Therefore, it is fundamental to investigate with various diagnostic strategies how the level of English brings with them the cycle that ends, which will allow them to start from the fortresses and weaknesses found in the process of acquiring new knowledge (MINED, 2018).

Another important part of the teacher's role in the transition from primary to secondary school is the attention they pay to the relationship or interaction with the student. Then according to Pianta (2001), in a series of descriptive studies based on the information provided by the teachers themselves, it was found that there are three dimensions in the relationship that occurs between students and teachers: conflict, closeness, and dependence, being proportionally corresponding to a certain level of learning achieved. The teacher-student relationship marked by closeness unfolds in an environment where teachers perceive strong levels of warmth, affection, and good communication by the students, which gives them a feeling of efficiency in the management of the class and generates confidence comfort in relationships that they generate with their students. For the student, this type of close relationship with his teacher generates security and can be used to provide concrete opportunities for learning within the classroom. In this regard, Pianta (2001) points out that the child who has a close relationship with the teacher tends to focus their attention and will on learning. Such characteristics of the close relationship make it ideal for facilitating a stress-free or trauma-free transition from primary to secondary school. In other words, the teacher can use the affection that he generates before the school group to promote the best adaptation of these students when facing a new scenario, new challenges, and even a new language in the case of English, assuming the role of 
guide and mentor in this case.

Regarding the trust produced in a close relationship between the teacher and the student, Casassus (2006) points out that when students are confident, they feel safe, and anxiety is reduced. Allowing them to be more like themselves in their originality can be open to participation in class without fear of making mistakes. This could be particularly useful in teaching English, where naturally, students, as part of their learning, often make mistakes when trying to write and speak in the new language.

Hence, by fostering an environment of trust in the classroom, the teacher reduces stress levels, anguish, and anxiety that the student can feel due to entry into a new school year. This would also translate into a better perception of new academic disciplines, new content, and assignments. In short, a trusting classroom environment lightens the student's adaptation to his new field of educational development. But rather would constitute the basis for a motivational strategy for learning since "a good motivation to learn is based on establishing a climate of trust between the students and the teacher" (Gaviria, 2016: p. 29).

Based on the above, the fundamental characteristics of the teaching role in the primary to secondary transition are: On the one hand, the disposition towards maintaining a motivational discipline allows the student to attend and understand a higher level of educational demand represented in a greater amount of content, higher depth, and a new schedule. And on the other hand, the interest in creating a close relationship with the student, leading to the latter see teachers as someone who guides students in overcoming the challenges of their entry to the new stage of the educational cycle. Both features are specially required by the English teacher, as teaching a foreign language leads to raising the levels of the challenge posed by the transition.

\section{Methodology}

\subsection{Type of Research}

The methodology of this research is limited to the positivist approach of a quantitative type, as it is based on the collection of data to prove a hypothesis. Thus, the desire to take a statistical analysis on students transitioning to secondary school is intended to study the academic, and educational factors affecting the transitional process. With this particularity, it seems appropriate to undergo in a logic of quantitative analysis, where the main goal for the researchers is to obtain precise numerical data that allows a generalization of research findings (Johnson \& Onwuegbuzie, 2004). Specifically, based on the numerical measurement and statistical analysis seeks to establish a relationship pattern between the factors associated with the transition process that occurs between primary and secondary school and the influence of these factors in the attitude and level of English language learning of the eighth-grade students of public education in Guayaquil city. Regarding the research design, it is considered non-experimental, cross-sectional, descriptive, and correlational. This considers what Hernández, Fernández and 
Baptista (2010) state that in non-experimental studies, the researchers have no control over the investigated variables. Specifically, these same authors argue that a cross-sectional investigation collects data in a single moment, considering indicators in each variable presented by the subjects who are part of the study when the instruments are applied. Likewise, they indicate descriptive studies as those that describe the magnitude of the variables in the subjects that make up the sample. And the correlational ones describe relationships between those variables.

\subsection{Population and Sample}

The population or universe of study corresponds to the total number of English teachers who cooperate in the eighth grade of public educational institutions in Guayaquil city, quantified as 2983 subjects of investigation. The sample corresponds to this group of teachers' statistical determination according to the sampling formula applied to finite populations. As a result, it was a minimum sample of 340 English teachers. This number was expanded to 469 once the instrument was applied. It is important to mention that the participants involved in this study are English language teachers from primary and secondary level, meaning that the sample lays the foundation for follow-up studies that intends to explore teachers' perceptions of the student transition to secondary level within the English language class, and provide a more deeply understanding of this particular educational reality.

\subsection{Techniques and Data Collection Instruments}

For data collection, the survey was used as a technique, which resulted in applying a questionnaire with 24 multiple choice response items to the group of teachers that make up the sample. Through this instrument, the teachers' aspects were fundamentally assessed during the teaching-learning process, emphasizing mainly their attention to the factors involved in the transition process from primary to secondary school students' experience.

\section{Results}

The main problem detected regarding English language teaching revolves around the teaching-learning aspects considered by the teachers of the eighth grade of public education in Guayaquil city. Specifically, it determined that these professionals' academic contents would not be considering some factors involved in the transition from primary to secondary level. The insufficient attention given to these factors by English teachers would be resulting in students not overcoming individual challenges, interactional and environmental that, according to the Griebel and Niesel model, are caused by the transition from one cycle to another, in this case from primary to secondary school. Failure to overcome these challenges can mean, in addition to deficient English language learning, the presence of frustration and lack of motivation for the future educational cycles. 
Among the factors not considered by English teachers in their curricular planning activities are the activities aimed at reinforcing discipline towards new content and establishing a close relationship with students. The case of the discipline can be seen because the new content was not introduced gradually and based on the results of a previous diagnosis. So, in most cases, the students did not receive previous training for this subject in their academic curricula during their first years of primary school because the English program is in force since the 2017 academic period in the coastal area which supposes a strong impact and generates little assimilation of this language in said students. The data found is displayed in the tables described below.

As shown in Table 2, the teachers indicate that the eighth-year students from public schools in Guayaquil have greater difficulties in learning the English language due to a much higher content than previous years, especially in the case of exercises involving the study of grammar rules. According to the Chi-square test, see Table 3, the link between the grade with the greatest English language learning difficulty and higher academic content compared to previous years is

Table 2. Academic content problems faced by students of BGE

\begin{tabular}{|c|c|c|c|c|c|c|c|c|}
\hline & & & \multicolumn{5}{|c|}{$\begin{array}{l}\text { C) } 8.2 \text {. Higher academic content in } \\
\text { contrast to the primary school years }\end{array}$} & \multirow{2}{*}{ Total } \\
\hline & & & Very low & Low & Medium & High & Very high & \\
\hline & \multirow{2}{*}{ rarely } & No. & 4 & 2 & 5 & 2 & 3 & 16 \\
\hline & & $\%$ & $25.0 \%$ & $12.5 \%$ & $31.3 \%$ & $12.5 \%$ & $18.8 \%$ & $100.0 \%$ \\
\hline & \multirow{2}{*}{ sometimes } & No. & 10 & 7 & 19 & 33 & 24 & 93 \\
\hline \multirow{7}{*}{$\begin{array}{c}\text { C) } 5.1 . \\
\text { grammar } \\
\text { exercises (activities } \\
\text { to study } \\
\text { grammar rules) }\end{array}$} & & $\%$ & $10.8 \%$ & $7.5 \%$ & $20.4 \%$ & $35.5 \%$ & $25.8 \%$ & $100.0 \%$ \\
\hline & \multirow{2}{*}{ frequently } & No. & 5 & 13 & 51 & 46 & 57 & 172 \\
\hline & & $\%$ & $2.9 \%$ & $7.6 \%$ & $29.7 \%$ & $26.7 \%$ & $33.1 \%$ & $100.0 \%$ \\
\hline & \multirow{2}{*}{ always } & No. & 10 & 14 & 41 & 62 & 61 & 188 \\
\hline & & $\%$ & $5.3 \%$ & $7.4 \%$ & $21.8 \%$ & $33.0 \%$ & $32.4 \%$ & $100.0 \%$ \\
\hline & \multirow{2}{*}{ Total } & No. & 29 & 36 & 116 & 143 & 145 & 469 \\
\hline & & $\%$ & $6.2 \%$ & $7.7 \%$ & $24.7 \%$ & $30.5 \%$ & $30.9 \%$ & $100.0 \%$ \\
\hline
\end{tabular}

Table 3. Chi-square tests in the correlation of learning difficulty and higher academic content.

\begin{tabular}{cccc}
\hline \multicolumn{4}{c}{ Chi-Square Tests } \\
\\
\hline Value & df & Asymp. Sig. (2-sided) \\
\hline Pearson Chi-Square & $24,923^{\mathrm{a}}$ & 12 & 0.015 \\
Likelihood Ratio & 21,605 & 12 & 0.042 \\
Linear-by-Linear Association & 6548 & 1 & 0.011 \\
N of Valid Cases & 469 & & \\
\hline
\end{tabular}

a. 5 cells $(25.0 \%)$ have expected count less than 5 . The minimum expected count is 0.99 . 
significant by 0.015 . This is lower than the margin of $5 \%$ error, so the relationship is accepted.

Despite the high academic content compared to previous years, eighth-grade teachers from public education in Guayaquil city do not apply strategies to promote greater confidence in the student. Such as the implementation of group work that will help foster collaborative work. Evidence of this is the results shown in Table 4 detailed below.

As shown in Table 4, teachers indicate that eighth-grade students of public education in Guayaquil city face a higher requirement in the subject than previous years without this implying a greater recurrence to group work and collaborative learning. This would be an indicator of the increased level of challenge students face in their new educational stage. According to the Chi-square test, see Table 5, the link between the frequency of workgroups involving collaborative learning and higher academic content compared to previous years is significant in 0.001 . This is less than the margin of $1 \%$ error, so the relationship is accepted.

Consequently, one of the problems eighth graders of public education in Table 4. Higher academic content with little focus on group activities

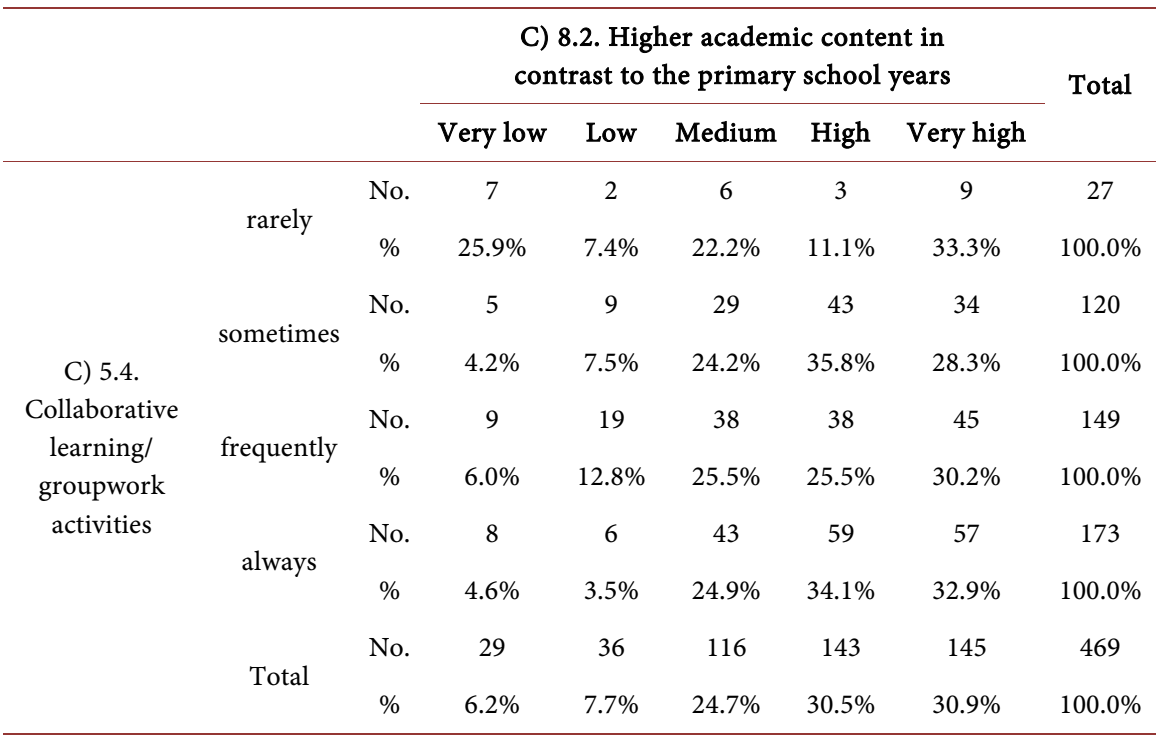

Table 5. Chi-square tests in the correlation of low frequency of groupwork activities group and higher academic content

\begin{tabular}{cccc}
\hline & Chi-Square Tests & \\
\hline & Value & df & Asymp. Sig. (2-sided) \\
\hline Pearson Chi-Square & $34,585^{\mathrm{a}}$ & 12 & 0.001 \\
Likelihood Ratio & 28,407 & 12 & 0.005 \\
Linear-by-Linear Association & 4580 & 1 & 0.032 \\
N of Valid Cases & 469 & & \\
\hline
\end{tabular}

a. 2 cells $(10.0 \%)$ have expected count less than 5 . The minimum expected count is 1.67 . 
Guayaquil city face is the lack of an English curriculum where group activities that promote collaborative work should prevail which without it would undoubtedly favor an accompaniment that would generate greater confidence during the teaching-learning process. This assumes that teachers implement individual exercises, such as activities for the study of grammar rules, that could raise the level of challenge and stress that students face upon entering a new educational cycle, especially when teaching English as a foreign language. A challenging situation that is increased and complicated by the teacher's lack of complement, mainly due to the high number of students to attend by course, as reflected in the following table.

As shown in Table 6, despite the increase in enrollment per course, eighthgrade English teachers of public education in Guayaquil city tend towards activities that involve the study of grammar rules, which involves performing exercises that are normally done individually. According to the Chi-square test, see Table 7, the relationship between the increase in the number of students per course and the completion of exercises aimed at learning grammar rules by

Table 6. Increase in school enrollment and the completion of grammar exercises.

\begin{tabular}{|c|c|c|c|c|c|c|c|c|}
\hline & & & \multicolumn{5}{|c|}{$\begin{array}{l}\text { C) 8.6. Increase of number } \\
\text { of students per class }\end{array}$} & \multirow{2}{*}{ Total } \\
\hline & & & Very low & Low & Medium & High & Very high & \\
\hline \multirow{10}{*}{$\begin{array}{l}\text { C) 5.1. grammar } \\
\text { exercises } \\
\text { (activities } \\
\text { to study } \\
\text { grammar rules) }\end{array}$} & \multirow{2}{*}{ rarely } & No. & 3 & 2 & 3 & 5 & 3 & 16 \\
\hline & & $\%$ & $18.8 \%$ & $12.5 \%$ & $18.8 \%$ & $31.3 \%$ & $18.8 \%$ & $100.0 \%$ \\
\hline & \multirow{2}{*}{ sometimes } & No. & 6 & 15 & 22 & 22 & 28 & 93 \\
\hline & & $\%$ & $6.5 \%$ & $16.1 \%$ & $23.7 \%$ & $23.7 \%$ & $30.1 \%$ & $100.0 \%$ \\
\hline & \multirow[t]{2}{*}{ frequently } & No. & 4 & 17 & 29 & 70 & 52 & 172 \\
\hline & & $\%$ & $2.3 \%$ & $9.9 \%$ & $16.9 \%$ & $40.7 \%$ & $30.2 \%$ & $100.0 \%$ \\
\hline & \multirow{2}{*}{ always } & No. & 6 & 13 & 33 & 45 & 91 & 188 \\
\hline & & $\%$ & $3.2 \%$ & $6.9 \%$ & $17.6 \%$ & $23.9 \%$ & $48.4 \%$ & $100.0 \%$ \\
\hline & \multirow{2}{*}{ Total } & No. & 19 & 47 & 87 & 142 & 174 & 469 \\
\hline & & $\%$ & $4.1 \%$ & $10.0 \%$ & $18.6 \%$ & $30.3 \%$ & $37.1 \%$ & $100.0 \%$ \\
\hline
\end{tabular}

Table 7. Chi-square tests in the correlation of the frequency of grammar exercises and the increase in the number of students per course.

\begin{tabular}{cccc}
\hline \multicolumn{4}{c}{ Chi-Square Tests } \\
\\
\hline Value & df & Asymp. Sig. (2-sided) \\
\hline Pearson Chi-Square & $39,866^{\mathrm{a}}$ & 12 & 0.000 \\
Likelihood Ratio & 35,139 & 12 & 0.000 \\
Linear-by-Linear Association & 18,673 & 1 & 0.000 \\
N of Valid Cases & 469 & & \\
\hline
\end{tabular}

a. 5 cells $(25.0 \%)$ have expected count less than 5 . The minimum expected count is 0.65 . 
eighth-grade students of public education in Guayaquil city is significant at 0.000 . This is less than the $1 \%$ margin of error so that the relationship is accepted.

Conversely, even though group activities would help reduce support needs in classes where there has been an increase in students' number, these are not incorporated very frequently by the English teachers of public education in Guayaquil city. Likewise, group activities tend to promote the construction of an environment of greater interaction, which would undoubtedly promote a close relationship between students and teachers. Circumstances that are not perceived within the aspects of the teaching English language learning carried out in educational institutions indicated, as can be seen in the table below.

As shown in Table 8, the eighth-grade English teachers of public education in Guayaquil city, compared to individual grammar learning exercises, have less tendency to incorporate into their educational planning group activities. Through collaborative work, this could provide greater opportunities for establishing a close relationship with their students, which would be beneficial to reduce the impact of the influence of some factors of the transition from primary to secondary on English language learning. According to the Chi-square test, see $\mathrm{Ta}$ ble 9, the link between the frequency of workgroups involving collaborative learning and the increase in the number of students per course is significant by 0.014 , which is slightly higher than the margin of error of $1 \%$, thus accepting the relationship.

Continuing with the teaching role's characterization during the transition from primary to secondary in terms of academic and didactic materials used to cover the teaching-learning process of English in eighth grade of public education in Guayaquil city. It can be noted that the traditional exercises that encourage students to study grammar rules are not conducive to a close teacher-student relationship, since it involves individual activities where students usually use

Table 8. Little focus on group activities in conditions of increased school enrollment.

\begin{tabular}{|c|c|c|c|c|c|c|c|c|}
\hline & & & \multicolumn{5}{|c|}{ C) 8.6. Increase of number of students per class } & \multirow{2}{*}{ Total } \\
\hline & & & Very low & Low & Medium & High & Very high & \\
\hline \multirow{10}{*}{$\begin{array}{c}\text { C) } 5.4 . \\
\text { Collaborative } \\
\text { learning/ } \\
\text { groupwork } \\
\text { activities }\end{array}$} & \multirow{2}{*}{ rarely } & No. & 4 & 6 & 6 & 4 & 7 & 27 \\
\hline & & $\%$ & $14.8 \%$ & $22.2 \%$ & $22.2 \%$ & $14.8 \%$ & $25.9 \%$ & $100.0 \%$ \\
\hline & \multirow[t]{2}{*}{ sometimes } & No. & 4 & 12 & 26 & 42 & 36 & 120 \\
\hline & & $\%$ & $3.3 \%$ & $10.0 \%$ & $21.7 \%$ & $35.0 \%$ & $30.0 \%$ & $100.0 \%$ \\
\hline & \multirow[t]{2}{*}{ frequently } & No. & 7 & 12 & 27 & 50 & 53 & 149 \\
\hline & & $\%$ & $4.7 \%$ & $8.1 \%$ & $18.1 \%$ & $33.6 \%$ & $35.6 \%$ & $100.0 \%$ \\
\hline & \multirow{2}{*}{ always } & No. & 4 & 17 & 28 & 46 & 78 & 173 \\
\hline & & $\%$ & $2.3 \%$ & $9.8 \%$ & $16.2 \%$ & $26.6 \%$ & $45.1 \%$ & $100.0 \%$ \\
\hline & \multirow{2}{*}{ Total } & No. & 19 & 47 & 87 & 142 & 174 & 469 \\
\hline & & $\%$ & $4.1 \%$ & $10.0 \%$ & $18.6 \%$ & $30.3 \%$ & $37.1 \%$ & $100.0 \%$ \\
\hline
\end{tabular}


memorization and a bilingual dictionary. In other words, the use of these activities does not stimulate the teacher's participation as a guide or mediator. The characterization of these aspects of teaching-learning in the institutions addressed can be seen in the following table.

As shown in Table 10, in the academic and didactic material employed by eighth-grade English teachers of public education in Guayaquil city predominate those normally used to perform exercises grammar, being the bilingual dictionary one of them. It is a resource that considers individual use as the main characteristic, not allowing for produce sustained interaction between teacher and student. According to the Chi-square test, see Table 11, the relationship between the lack of materials academic and didactic to carry out the English teaching-learning process in the eighth-grade of public education in Guayaquil city and carrying out exercises focused on the study of the rules is significant at 0.023 . This is slightly greater than the $1 \%$ margin of error, so the relationship is accepted.

Table 9. Chi-square tests in the correlation of workgroup activities frequency and the increase in the number of students per course.

\begin{tabular}{cccc}
\hline \multicolumn{4}{c}{ Chi-Square Tests } \\
& Value & df & Asymp. Sig.(2-sided) \\
\hline Pearson Chi-Square & $25,204^{\mathrm{a}}$ & 12 & 0.014 \\
Likelihood Ratio & 21,767 & 12 & 0.040 \\
Linear-by-Linear Association & 10,989 & 1 & 0.001 \\
N of Valid Cases & 469 & & \\
\hline
\end{tabular}

a. 3 cells $(15.0 \%)$ have expected count less than 5 . The minimum expected count is 1.09.

Table 10. Excessive focus on grammar exercises in a deficient scenario of academic and didactic resources.

\begin{tabular}{|c|c|c|c|c|c|c|c|c|}
\hline & & & \multicolumn{5}{|c|}{$\begin{array}{l}\text { C) 8.7. Lack of academic and didactic resources to meet the } \\
\text { class needs during the English teaching-learning process }\end{array}$} & \multirow{2}{*}{ Total } \\
\hline & & & Very low & Low & Medium & High & Very high & \\
\hline \multirow{10}{*}{$\begin{array}{l}\text { C) } 5.1 . \\
\text { grammar } \\
\text { exercises } \\
\text { (activities } \\
\text { to study } \\
\text { grammar } \\
\text { rules) }\end{array}$} & \multirow{2}{*}{ rarely } & No. & 3 & 3 & 4 & 1 & 5 & 16 \\
\hline & & $\%$ & $18.8 \%$ & $18.8 \%$ & $25.0 \%$ & $6.3 \%$ & $31.3 \%$ & $100.0 \%$ \\
\hline & \multirow{2}{*}{ sometimes } & No. & 10 & 10 & 10 & 39 & 24 & 93 \\
\hline & & $\%$ & $10.8 \%$ & $10.8 \%$ & $10.8 \%$ & $41.9 \%$ & $25.8 \%$ & $100.0 \%$ \\
\hline & \multirow{2}{*}{ frequently } & No. & 12 & 23 & 39 & 51 & 47 & 172 \\
\hline & & $\%$ & $7.0 \%$ & $13.4 \%$ & $22.7 \%$ & $29.7 \%$ & $27.3 \%$ & $100.0 \%$ \\
\hline & \multirow{2}{*}{ always } & No. & 11 & 21 & 42 & 46 & 68 & 188 \\
\hline & & $\%$ & $5.9 \%$ & $11.2 \%$ & $22.3 \%$ & $24.5 \%$ & $36.2 \%$ & $100.0 \%$ \\
\hline & \multirow{2}{*}{ Total } & No. & 36 & 57 & 95 & 137 & 144 & 469 \\
\hline & & $\%$ & $7.7 \%$ & $12.2 \%$ & $20.3 \%$ & $29.2 \%$ & $30.7 \%$ & $100.0 \%$ \\
\hline
\end{tabular}


Table 11. Chi-square tests in the correlation of grammar exercise frequency and the lack of didactic and academic resources.

\begin{tabular}{cccc}
\hline \multicolumn{4}{c}{ Chi-Square Tests } \\
\\
\hline Value & df & Asymp. Sig. (2-sided) \\
\hline Pearson Chi-Square & $23,634^{\mathrm{a}}$ & 12 & 0.023 \\
Likelihood Ratio & 24,392 & 12 & 0.018 \\
Linear-by-Linear Association & 2796 & 1 & 0.094 \\
N of Valid Cases & 469 & & \\
\hline
\end{tabular}

a. 5 cells $(25.0 \%)$ have expected count less than 5 . The minimum expected count is 1.23 .

\section{Discussion}

The results obtained indicate the relationship between learning English acquired by eighth-grade students of public education in Guayaquil city and the factors that influence the transition from primary to secondary school these students experience. Among the factors made visible is the preparation required to face academic content in greater quantity and complexity, and the teacher-student relationship.

Both factors combine to create a new educational environment, different from what students experienced in primary school. Together with others omitted in this study (for example, family support and educational infrastructure), this creates a complex moment for the student, who also faces a crucial stage and many doubts in their life, such as adolescence.

The transition from primary to secondary in these students can be accentuated not only because of the greater amount of academic content to be addressed in this new stage, but there is also the learning of a new language, English. This can influence an impact different from that which operates in other educational transition types (for example, from initial education to primary or secondary to university). So, in addition to the external changes that the student experiences when entering secondary school, it can produce a higher level of demand or challenge.

To face such challenges, theorists point to support from the group family and the stimulation of the student to behave disciplined in the face of new educational tasks, just as the teaching staff requires a curricular adaptation. The needs and educational demands are needed to gradually introduce the academic requirement superior characterizing the new stage compared to the primary level.

Likewise, the theory proposes that the part of the teacher establish a close relationship with the student since this would allow the latter to approach with less stress or anguish the proposed activities. That is, there would be more confidence and motivation towards the achievement of educational achievements.

However, according to the results obtained, the English teachers of the eighth grade of public education in Guayaquil city do not apply curricular planning adapted to students' transition. They are also posing predominantly grammatical exercises of individual completion, avoiding group work that through collabora- 
tive learning, they would promote a closer relationship between teacher and student.

Finally, results indicate that in order to ease the student transition to secondary level, teachers need to take into consideration content, academic, and environmental factors. Thus, practical applications from the results obtained give English teachers the rationale to reflect of this transitional process, to adapt their content planning, and adjust their teaching-learning process, as a mean to achieve a positive student transition. Besides, not only teachers, but also other educational stakeholders can promote educational projects where teachers, parents, and school principals are involved throughout this educational process to significantly facilitate the student transition in terms of the academic, social, and environmental factors.

\section{Conclusion}

Through the research carried out, it was possible to show the level of influence that exerts factors linked to the transition from primary to secondary in the English language of eighth-grade students of public education in Guayaquil city. Specifically, it was found that factors such as discipline requirement and the close relationship between the student and the teacher would influence the student's confidence and motivation towards learning English. Specifically, Griebel and Niesel's description of the transition model approached from a perspective of English's teaching-learning process in students transitioning from primary to secondary school. Among the factors described and others such as family support and educational infrastructure changes, the study determined that challenges occur at the individual, interactional or environmental level.

Such challenges pose the need for the teacher to assume specific strategies and activities, recommending the theory of gradual implementation of higher contents and adapted to the results of the diagnosis of previous knowledge in the students, as well as the implementation of activities that promote the establishment of close relationships with the student. Such recommendations are inscribed both within the input hypothesis and affective filter of Krashen and Terrel. The first stated that people could acquire language when they understand and are exposed to a constant linguistic stimulus slightly above the current competition level. And from the hypothesis of the affective filter, it is argued that when a student has a positive vision towards the learning process, they will have more successful in acquiring the foreign language than students who are not motivated.

\section{Acknowledgements}

This work is financed by National Funds through the FCT (Foundation for Science and Technology) within the framework of CIEC (Research Centre on Child Studies at the University of Minho) with the reference UID/CED/00317/2019. 


\section{Conflicts of Interest}

The authors declare no conflicts of interest regarding the publication of this paper.

\section{References}

Antunez, S., (2005). El cuidado de los procesos de transición de primaria a secundaria: A modo de balance [Taking Care of the Transition Processes from Primary to Secondary: As a Balance]. Aula De Innovación Educativa, 142.

https://www.researchgate.net/publication/39212121_El cuidado de los procesos de t ransicion de primaria a secundaria a modo de balance

Arechúa, S. (2012). El diseño curricular formal de lengua extranjera y suincidenciaen el proceso de enseñanza aprendizaje del idioma inglés en los estudiantes de octavo año de educación básica del paralelo G del colegio fiscal "El Empalme" provincia del Guayas período lectivo 2011-2012 [The Formal Curricular Design of a Foreign Language and Its Incidence in the Teaching-Learning Process of the English Language in Students in the Eighth Year of Basic Education of Parallel G of the Fiscal School "El Empalme" Province of Guayas School Period 2011-2012]. Babahoyo: Universidad Técnica de Babahoyo, Facultad de Ciencias Jurídicas, Sociales y de la Educación.

http://dspace.utb.edu.ec/bitstream/handle/49000/1327/T-UTB-FCJSE-IDIOMAS-0000 06.02.pdf? sequence $=2$ \&isAllowed $=y$

Barrezueta, D., \& Merlo, E. (2010). Conocimientos heterogéneos del idioma inglés que presentan los estudiantes del sector rural y urbano al iniciar el octavo año de educación básica del Colegio Nacional Atahualpa [Heterogeneous Knowledge of the English Language Presented by Students from the Rural and Urban Sectors at the Beginning of the Eighth Year of Basic Education at the Atahualpa National School]. Ibarra: Universidad Técnica del Norte-Facultad de Educación, Ciencia y Tecnología.

http://repositorio.utn.edu.ec/bitstream/123456789/378/3/FECYT\%20967\%20\%20DESA RROLLO\%20DEL\%20PROYECTO.pdf

Bronfenbrenner, U. (1979). The Ecology of Human Development. Experiments by Nature and Design. Cambridge: Harvard University Press.

https://khoerulanwarbk.files.wordpress.com/2015/08/urie bronfenbrenner the ecolog y of human developbokos-z1.pdf

Casassus, J. (2006). La educación del ser emocional [The Education of the Emotional Being]. Santiago de Chile: Índigo/Cuarto propio.

https://www.academia.edu/33769023/Casassus Juan La Educacion Del Ser Emocion al_pdf

Castro, A., Ezquerra, P., \& Argos, J. (2012). La transición entre la escuela de educación infantile y la de educación primaria: Perspectivas de niños, familias y profesorado [The Transition between Early Childhood School and Primary School: Perspectives of Children, Families and Teachers]. Revista Española De Pedagogía, LXX, 537-552.

Cerdas, G., \& Ramírez, J. (2015). La enseñanza de lenguas extranjeras: Historia, teoría y práctica [Teaching Foreign Languages: History, Theory and Practice]. Revista de Lenguas Modernas, 22, 297-316. https://doi.org/10.15517/rlm.v0i22.19687

Cowan, P. (1991). Individual and Family Life Transitions: A Proposal for a New Definition (pp. 3-30). Hillsdale, NJ: Lawrence Erlbaum Associates, Inc.

Fabian, H., \& Dunlop, A.-W. (2007). Outcomes of Good Practice in Transition Process for Children Entering Primary School. The Hague: Bernard van Leer Foundation. https://www.researchgate.net/publication/252093921 Outcomes of Good Practice in Transition Process for_Children Entering Primary School 
Fabuel, V. (2015). Una reflexión sobre las transiciones educativas: de Primaria a Secundaria ¿traspaso o acompañamiento? [A Reflection on Educational Transitions: From Primary to Secondary, Transfer or Accompaniment?]. Edetania: estudios y propuestas socio-educativas, 48, 159-184. https://dialnet.unirioja.es/servlet/oaiart?codigo $=5349094$

Filipp, S., (1981). Ein allgemeines modell für die analyse kritischer lebensereignisse [A general model for the analysis of critical life events]. Forschungsberichte Aus Dem Projekt Entwicklungspsychologie Des Erwachsenenalters, 13.

Gairín, J. (2004). La transición entre etapas educativas [The Transition between Educational Stages]. VIII Congreso Interuniversitario de Organización de Instituciones Educativas, Sevilla, 10-12 November 2004.

http://ateneu.xtec.cat/wikiform/wikiexport/ media/formgest/equips directius/st10/blo c $2 /$ transicion entre etapas educativas.pdf

Gaviria, M. (2016). La transición de la educación primaria a la educación secundaria, un asunto por entender $y$ atender desde la cotidianidad escolar [The Transition from Primary Education to Secondary Education, a Matter to Be Understood and Addressed from the Daily School Life]. Caldas-Antioquia: Corporación Universitaria Lasallista, Facultad de Ciencias Sociales y Educación, Especialización en Psicología Educativa. http://repository.lasallista.edu.co/dspace/bitstream/10567/1679/1/Transicion educacio n primaria secundaria.pdf

Griebel, W., \& Niesel, R. (2004). Transitionen: Fähigkeit von kindern in tageseinrichtungen fördern, veränderungen erfolgreich zu bewältigen (beiträge zur bildungsqualität) [Transitions: Promoting the Ability of Children in Day-Care Centers to Successfully Cope with Change (Contribution to the Quality of Education)]. Weinheim: Beltz.

Hernández, R., Fernández, C., \& Baptista, P. (2010). Metodología de la investigación [Investigation Methodology]. México DF: Mc Graw Hill.

https://www.uca.ac.cr/wp-content/uploads/2017/10/Investigacion.pdf

Hiraldo, M. (2018). Transición de primaria a secundaria [Transition from Primary to Secondary].

https:/listindiario.com/la-vida/2018/08/12/528273/transicion-de-primaria-a-secundaria

Hockett, C. F. (1967). A Course in Modern Linguistics. New York: The Macmillan Company. https://onlinelibrary.wiley.com/doi/abs/10.1111/j.1467-1770.1958.tb00870.x

Johnson, R. B., \& Onwuegbuzie, A. J. (2004). Mixed Methods Research: A Research Paradigm Whose Time Has Come. Educational Researcher, 33, 14-26. https://doi.org/10.3102/0013189X033007014

Krashen, S., \& Terrell, T. (1983). The Natural Approach: Language Acquisition in the Classroom. Michigan: Pergamon Press. http://www.sdkrashen.com/content/books/the natural approach.pdf

Lazarus, R. S., \& Folkman, S. (1987). Transactional Theory and Research on Emotions and Coping. European Journal of Personality, 1, 141-169.

https://doi.org/10.1002/per.2410010304

MINED (2018). MINED capacita a docentes de educación secundaria. https://www.mined.gob.ni/mined-capacita-a-docentes-de-educacion-secundaria/

Pianta, R. (2001). Student-Teacher Relationship Scale-Short Form. Florida: Psychological Assessment Resources, Inc. https://curry.virginia.edu/sites/default/files/uploads/resourceLibrary/STRS-SF.pdf

Real Academia Española (RAE) (2019). Transición/Diccionario de la lengua española. https://dle.rae.es/transición

Vogler, P., Crivello, G., \& Woodhead, M. (2008). La investigación sobre las transiciones en la primera infancia: Análisis de nociones, teorías y practices [Research on Early 
Childhood Transitions: Analysis of Notions, Theories, and Practices]. Cuadernos Sobre Desarrollo Infantil Temprano, 48.

https://www.oei.es/historico/pdf2/analisis transiciones primera infancia.pdf

Voli, F. (2005). Sentirse bien en el aula: Manual de convivencia para profesores [Feeling Good in the Classroom: Coexistence Manual for Teachers]. Madrid: PPC.

Welzer, H. (1993). Transitionen: Zur sozialpsychologie biographischer wandlungsprozesse [Transitions: On the Social Psychology of Biographical Change Processes]. Edition Diskord.

Wilcock, A. (2014). De la primaria a la secundaria: Cómo apoyar a los estudiantes en la transición [Elementary to High School: How to Support Students in Transition]. Madrid: Narcea Ediciones. 